\title{
A Utopia or Reality: Possibility of Using the Proper Law of Contract throughout an International Commercial Arbitration Claim
}

\author{
Karawita Arachchige Akalanka Nuwan Thilakarathna \\ Institute of Human Resource Advancement, University of Colombo, Colombo, Sri Lanka \\ Email: akalanka@ihra.cmb.ac.lk
}

How to cite this paper: Thilakarathna, K. A. A. N. (2021). A Utopia or Reality: Possibility of Using the Proper Law of Contract throughout an International Commercial Arbitration Claim. Beijing Law Review, 12, $1-15$.

https://doi.org/10.4236/blr.2021.121001

Received: December 30, 2020

Accepted: January 30, 2021

Published: February 2, 2021

Copyright ( 2021 by author(s) and Scientific Research Publishing Inc. This work is licensed under the Creative Commons Attribution International License (CC BY 4.0).

http://creativecommons.org/licenses/by/4.0/ (c) (i) Open Access

\begin{abstract}
International commercial arbitration has become the most favoured method of dispute resolution in the international arena since it has the capability of providing a win-win situation for the parties involved in the dispute which is not available under ordinary litigation. However, since arbitration is a matter of choice for the parties, the concept of party autonomy sometimes makes the arbitration process a difficult one to be conducted with the vigor that is found under court proceedings. One main reason for this can be seen in the multiplicity of laws that are involved in settling the dispute from the agreement to arbitrate to enforcing the claim. This article therefore looks at the possibility of adopting the proper law of contract to be applied throughout the process of arbitration in settling the dispute. Using the doctrinal approach by using international legal instruments, statues and decided case law as primary sources and using scholarly articles and books written on the subject, the results have shown that, while being highly optimistic, such an endeavour is not still possible since there is no single international legal document which deals with the whole process of arbitration and in such an absence, it seems difficult at the moment to use a single system of law throughout the arbitration process. Nevertheless, the article makes suggestions as to how such a mechanism could be implemented and the possible prospects and challenges in making this utopia a reality.
\end{abstract}

\section{Keywords}

International Arbitration, Law of Contract, Applicable Law, International Trade Law 


\section{Introduction}

In recent years, many of the commercial disputes in particular have been settled through the mechanism of arbitration. Arbitration has become a popular model of alternative dispute resolution (ADR) for its swiftness and flexibility in providing solutions in the commercial field where time is considered as a valuable asset itself. Redfern and Hunter observe that, due to the increased number of international commercial dealings by private individuals, corporations and States alike, as a mechanism of dispute resolution, arbitration has found a propound place the world over (Redfern \& Hunter, 2015).

Arbitration can be defined as a private system of adjudication where the parties who arbitrate have decided to resolve their disputes outside the judicial system of a state (Moses, 2012). In the case of (Motunui Ltd. v. Methanex Spellman, 2004), the court defined arbitration as "a contractual method of resolving disputes. By their contract, the parties agree to entrust the differences between them to the decision of an arbitrator or panel of arbitrators, to the exclusion of the Courts, and they bind themselves to accept that decision, once made, whether or not they think it right". However, it is to be noted that, if parties have agreed to settle their disputes through the use of arbitration, that rights should be reciprocal for both the parties and not at the instance of one party over the other. In the case of (Mme X v Banque Privée Edmond de Rothschild, 2013), it was stated that, where an arbitration clause provided one party with a unilateral right to decide whether to refer a dispute to a state court or to an arbitration tribunal to the exclusion of the other, such an arbitrational clause would become unenforceable for lack of mutuality of obligation. According to Article 2 of the the United Nations Commission on International Trade Law (UNCITRAL) Model Uniform Law, arbitration means any arbitration whether or not administered by a permanent arbitral institution.

While the judicial attitude in the modern era is in favour of arbitration, initially it was seen as an invasion on the jurisdiction of the courts of law since arbitration ousted the ability of a court to intervene in a dispute between two private individuals since they have agreed to do so. Courts initially considered this as something that was against public policy and it was in the decision of (Scott $\mathrm{v}$ Avery, 1856) where the court recognized the fact that, where there is an agreement to arbitrate, a cause of action will not arise until the parties have gone to the arbitration.

International Arbitration for the most part has evolved from the time where it was thought of as being intruding upon the judicial functions of the courts. Even with the expansion of international commercial arbitration in this regard, the absence of a universally accepted, single coherent legal instrument that could be utilized throughout the arbitral process has at times brought about complexities and controversies with regard to the applicable law in the different stages of the arbitral process and the main objective of this article is to find out whether it would be a viable solution to use the proper law of contract throughout the enti- 
rety of the arbitral process.

\section{Domestic and International Arbitration}

Arbitration can either be domestic or international (Redfern \& Hunter, 2015). The difference between domestic and international arbitration is made by having reference to the actual practice of arbitration than by the use of legal instruments (Redfern \& Hunter, 2015). According to Redfern and Hunter, there are four differences between domestic and international arbitration. Firstly, in international arbitration, the parties would normally not have any connection with the seat of arbitration or the place of arbitration since they would admire the idea of neutrality. Secondly, in most instances the parties to an international arbitration would be corporations, states or state entities and not private individuals. Thirdly, the sums involved in international arbitrations would be much higher than what you would find under domestic arbitrations. Fourthly, many countries have adopted different legal regimes to deal with international arbitrations (Redfern \& Hunter, 2015). According to a booklet (ICC, 1977) issued by the International Chamber of Commerce (ICC) "[T] he international nature of the arbitration does not mean that the parties must necessarily be of different nationalities. By virtue of its object, the contract can nevertheless extend beyond national borders, when for example a contract is Concluded between two nationals of the same State for performance in another country, or when it is concluded between a State and a subsidiary of a foreign company doing business in that State".

Further, in the case of (Fung Sang Trading Ltd. v. Kaisun Sea Products \& Food Co. Ltd., 1992) it was held that, "[a]n arbitration will still be international, despite both parties having their places of business in the same State, if any place where a substantial part of the obligations of the commercial relationship is to be performed, or the place with which the subject matter of the dispute is most closely connected is outside the State in which the parties have their place of business". UNCITRAL Model Law sets out certain criteria that may be looked into in determining whether the arbitration in question is international or not. The criteria states that, an arbitration is international if: 1) the parties to an arbitration agreement have, at the time of the conclusion of that agreement, their places of business in different States; or 2) one of the following places is situated outside the State in which the parties have their places of business: i) the place of arbitration if determined in, or pursuant to, the arbitration agreement; ii) any place where a substantial part of the obligations of the commercial relationship is to be performed or the place with which the subject matter of the dispute is most closely connected; or 3) the parties have expressly agreed that the subject matter of the arbitration agreement relates to more than one country (Model Law Article 1 Under).

\section{The Arbitration Process}

If any it has to be remembered that arbitration is a process and not a one of ad- 
venture. According to Redfern and Hunter (Redfern \& Hunter, 2015) in an international arbitration there are six key elements and it includes; an agreement to arbitrate, a dispute, commencement of an arbitration, arbitral proceedings, decision of the tribunal and the enforcement of the award. Ilias Bantekas (Bantekas, 2015) breaks down the arbitration process into three phases which includes; the agreement to arbitrate, the arbitral process and recognition and enforcement of foreign arbitral awards abroad.

An agreement to arbitrate is considered as the foundation stone of modern international arbitration. Before there can be a valid arbitration, there must first be a valid agreement to arbitrate. Since arbitration is not an ordinary means of resolving disputes it may only be employed if the parties have expressly provided for it by mutual consent. Under both The Convention on the Recognition and Enforcement of Foreign Arbitral Awards (New York Convention) Art. V and the Model Law Art. 35, recognition and enforcement of an arbitral award may be refused if the parties to the arbitration agreement were under some incapacity or if the agreement was not valid under its own governing law.

An agreement to arbitrate can be included in the main contract as a clause. Arbitration clauses are drawn up and agreed as part of the contract prior to any dispute has arisen, and so they necessarily look to the future. The parties naturally assume or hope that no dispute will arise. However, they agree that where such a dispute may arise, it will be resolved through arbitration. Another way for parties to agree to arbitrate is when a dispute has actually arisen. Such an agreement is generally known as a "submission agreement". Such an agreement would be much more comprehensive than a mere arbitration clause found in a contractual agreement and as such a submission agreement could include the whole process that should be followed in the arbitration. Further to this, when two states sign a bilateral investment treaty (BIT) with one another, such BIT can make provisions for arbitration between the contracting states and an investor. However, one must remember that in such an arbitration one party must be either a state- or state-owned institute/department whom is having a dispute with an investor. Therefore, two private individuals cannot use the arbitration agreement entered into by two states in a BIT for their own use.

Once there is a valid agreement to arbitrate any of the parties to the agreement may trigger it and initiate arbitral proceedings. The initiating party (the plaintiff or claimant) will commence the process by transmitting a statement of claim to the parties' chosen arbitral institution, or directly to the respondent or its designated agent, depending on the pertinent institutional rules. The respondent on the other hand will be afforded a time frame within which to respond to the claim and raise any objections. If the objections concern the validity of the agreement to arbitrate the respondent will seek to prevent the constitution of the tribunal through a variety of options. In the absence of jurisdictional disputes, the parties will select the persons whom they want to appoint as arbitrators. When all procedural challenges have been resolved by mutual agreement, or by 
the tribunal in accordance with the lex arbitri or the applicable institutional rules, the discussion of the merits will take place.

One the tribunal has deliberated on the merits and the other aspects pertaining to the arbitration, it can either decide whether there is a breach by one party which makes the other party liable or that no breach has occurred or that the counter claim must stand. If the tribunal either decides to make an award to the claim or the counter claim, that award would have to be enforced within the jurisdiction where it lies. In most cases, particularly between businesses that wish to remain creditworthy and reputable, awards are complied with voluntarily without further challenges, but situations do arise where a party challenges not only the validity of the award but also the validity of the arbitral process and even the existence of an arbitration agreement. The enforcement of an arbitral award is governed by the 1958 New York Convention where the signatory states have been obliged to recognize the existence of foreign awards and enforce them in their territory against the assets of nationals and non-nationals alike, save for assets covered by the privilege of sovereign immunity (Bantekas, 2015).

\section{Different Laws Applicable in the Arbitration Process}

Ilias Bantekas (Bantekas, 2015) observes that, the richness of arbitration is reflected in the nature and diversity of these rules. According to Redfern and Hunter, international arbitration, unlike its domestic counterpart, usually involves more than one system of law or of legal rules. They further explain that, in the arbitration process as a whole, one may come across five different systems of law that, in practice, may have a bearing on an international arbitration. These laws include; the law governing the arbitration agreement and the performance of that agreement, the law governing the existence and proceedings of the arbitral tribunal (the lex arbitri), the law, or the relevant legal rules, governing the substantive issues in dispute (generally described as the "applicable law", the "governing law", "the proper law of the contract", or "the substantive law"), other applicable rules and non-binding guidelines and recommendations and the law governing recognition and enforcement of the award (which may, in practice, prove to be not one law, but two or more, if recognition and enforcement is sought in more than one country in which the losing party has, or is thought to have, assets) (Redfern \& Hunter, 2015).

As described above, at least five systems of law would become applicable in an arbitration process and one may wonder whether a single system of law could be used to govern all the different stages of the arbitration process. In this regard one could argue that, since the parties initially consented to the original contract which gave rise to the arbitration process, whatever law that was supposed to govern the original contract or the proper law of contract should be applied throughout the arbitration process and that it would be advantageous for both the parties. While this may be a bold and utopian statement, one has to critically analyze the arbitration process in finding whether there is any merit in arguing 
for such an approach.

\subsection{Application of the Proper Law of Contact to the Agreement to Arbitrate}

An agreement to arbitrate, as explained above, may be set out in a purpose made submission agreement or as is the case much more frequently in an arbitration clause. It is also to be noted that, even if the agreement to arbitrate is only contained in the main contract as a simple clause, it would be treated as a separate agreement and this is termed as separability. This concept basically means that, the arbitration clause in a contract is considered to be separate from the main contract of which it forms part and, as such, survives the termination of that contract. In the case of (Heyman v Darwins Ltd., 1942) it was held that, "an arbitration clause survives for the purpose of measuring the claims arising out of the breach, and the arbitration clause survives for determining the mode of their settlement. The purposes of the contract have failed, but the arbitration clause is not one of the purposes of the contract". Further, in the case of (Gosset v. Carapelli, 1963) the French court held that, in international arbitration, the agreement to arbitrate, whether concluded separately or included in the contract to which it relates, is always save in exceptional circumstances, is completely autonomous in law, which excludes the possibility of it being affected by the possible invalidity of the main contract'.

When it comes to the law applicable to the main contract between the parties, parties are at liberty to select any law that they want the contract to be governed with. This is well founded in the twin concepts of freedom of contract and part autonomy. If the parties have decided on a particular law that should govern their main agreement, the arbitration tribunal would have to respect that and apply the same. If the arbitrators dismiss the parties' choice of law, the award will almost certainly be defective and in addition they may incur some degree of liability for violating their mandate (acta ultra vires) (Bantekas, 2015).

Issues related to applicable law arises when the parties have either omitted or forgot to include or mention the law that governs their main contract. In such an instance, if the matter was to be dealt by a domestic court of the country, it will have to apply its own conflict of law rules in determining the applicable law under lex fori. However, unlike a domestic court of law, an arbitration tribunal does not have a lex fori and as far as national procedural law is concerned, they are only bound by the mandatory provisions of the law of their seat called lex arbitri. An arbitral tribunal is at liberty to decide on the applicable law according to its own decision which stems from the concept of competence-competence (Kompetenz-Kompetenz) which means that the arbitral tribunal is competent to decide the competence of its own jurisdiction (Savage, 1999). Article 28 (2) of the UNCITRAL Model Law provides that, failing any designation by the parties, the arbitral tribunal shall apply the law determined by the conflict of laws rules which it considers applicable. 
In the above circumstances, it becomes also important to consider the law that would become applicable for an agreement to arbitrate. If the agreement to arbitrate is tendered after a dispute has arisen in the form of a submission agreement, parties would normally include a provision stating the particular law that would govern the submission agreement. Even if the agreement to arbitrate is contained in the main agreement itself as a mere clause thereof, the parties are still at liberty to decide on the applicable law. Parties can decide that, one law or a legal system should govern the main agreement and another should govern the agreement to arbitrate and this stems for the concept of party autonomy. However, in most of the cases parties will omit to include an applicable law governing the agreement to arbitrate. In such instances, it has been argued that the law governing the main contract should be used to govern the agreement to arbitrate as well. In the case of (National Thermal Power Corporation v Singer Company, 1992) the Indian Supreme Court held that, "where the proper law of the contract is expressly chosen by the parties, (as in the present case), such law must in the absence of an unmistakable intention to the contrary, govern the arbitration agreement which, though collateral or ancillary to the main contact, is nevertheless a part of such contract". However, person observes that, this proposition has changed in the United Kingdom where he finds that, while traditionally the English courts had applied the law governing the substantive contract to the arbitration agreement, more recent judgments have applied the law of the seat of the arbitration (Pearson, 2013). She further points out that, the issue of the proper law applicable to the arbitration agreement is significant given that the arbitration agreement forms the bedrock of the arbitral tribunal's jurisdiction.

In the case of (Heyman v Darwins Ltd., 1942) it was stated that, according to English notions an arbitration clause in a contract constitutes a self-contained contract collateral or ancillary to the main contract of which it forms apart. It is this separability of an arbitration clause that opens the way for the possibility that it may be governed by a different law from that which governs the main agreement. Redfern and Hunter (Redfern \& Hunter, 2015) points out that, taking the idea of separability of the agreement to arbitrate, courts have decided to apply the law of the seat of arbitration as the applicable law regarding an agreement to arbitrate. They further point out that this approach has been also adopted in the London Court of International Arbitration, where under Article 16 (4) it states that, "the law applicable to the Arbitration Agreement and the arbitration shall be the law applicable at the seat of the arbitration, unless and to the extent that the parties have agreed in writing on the application of other laws or rules of law and such agreement is not prohibited by the law applicable at the arbitral seat".

In the case of (XL Insurance Ltd. v. Owens Corning, 2000) the court held that while parties had implicitly chosen the law of the seat rather than the law expressly chosen to govern the underlying contract as the proper law applicable to the arbitration clause. In arriving at this conclusion, the court pointed out that, 
"by stipulating/or arbitration in London under the provisions of the Arbitration Act, 1996 the parties chose English law to govern the matters which fell within those provisions including the formal validity of the arbitration clause and the jurisdiction of Ike arbitral tribunal; and by implication chose English law as the proper law of the arbitration". Moving forward, in the case of (C v D, 2007) the parties had chosen New York law to govern the underlying contract and London as the seat of the arbitration yet the Court of Appeal held obiter that the arbitration agreement had it closest and most real connection with the law of the seat of the arbitration rather than the law expressly chosen to govern the underlying contract. In the case of (Sulamerica CIA Nacional de Seguros S.A. and others v. Enesa Engenharia S.A. and others, 2012), the underlying contract was governed by Brazilian law and the arbitration agreement provided for London as the seat of the arbitration. The Commercial Court considered that the key question was the weight to be given to the choice of London as the seat of the arbitration and noted that the seat of the arbitration determined the procedural law and the supervising jurisdiction of the courts of the country where the seat is located. In this case, the English Court of Appeal accepted that it was fair to start from the assumption that, in the absence of any contrary indication, the parties intended the whole of their relationship to be governed by the same system of law. Starting from that assumption, the "natural inference" was that the parties intended that law chosen to govern the substantive contract also to govern the agreement to arbitrate. However, the English Court of Appeal held that, in the present case, two specific factors indicated that the parties did not intend that Brazilian law should govern the arbitration agreement. First, it was argued that, under Brazilian law, the arbitration agreement was enforceable only with Enesa's consent. The English Court of Appeal recognized that there was no indication that the parties intended the arbitration agreement to be enforceable by only one party and, accordingly, there was a serious risk that a choice of Brazilian law would entirely undermine the arbitration agreement. Secondly, the choice of London as the seat of arbitration entailed acceptance by the parties that English law would apply to the conduct and supervision of the arbitration, which suggested that the parties intended English law to govern all aspects of the arbitration agreement (Redfern \& Hunter, 2015). Further, in the case of (Abuja International Hotels Ltd. v. Meridien SAS, 2012), the Commercial Court again held that the arbitration agreement was governed by the law of the seat of the arbitration (English law) rather than the law expressly chosen to govern the underlying contract (Nigerian law) given that the arbitration agreement had its closest and most real connection with the seat of the arbitration.

From the case law discussed above, it becomes apparent that the courts have shifted from the strict separatist approach and move towards a more validation approach. Gary Born (Born, 2009) argues that, the determination of the choice of law applicable to the arbitration agreement should be guided by a "validation principle" i.e., the principle that, it is the parties' intention to enter into a valid 
arbitration agreement and that it is die purpose of the international arbitral process to give effect to the parties' arbitration agreement. In this backdrop, one has to wonder whether using the proper law of contract would be beneficial to the parties, since the parties have agreed upon that. However, if one was to proceed with the agreement to arbitrate using the proper law of contract, since the agreement to arbitrate is also a distinct contract and where the proper law of contract applicable to the main contract was to make it a nullity, this would mean that the agreement to arbitrate would also become a nullity since the applicable law for both the main contract and the agreement to arbitrate would be the same. However, if the applicable law relating to the main contract and the agreement to arbitrate was different from one another, even if the main contract becomes a nullity, that would not affect the validity of the agreement to arbitrate since it would be governed by a different law. Therefore, it could be argued that, parties would not simply benefit from applying the same law that governs their main agreement to the agreement to arbitrate.

On the other hand, there are some scholars who argue for a uniformity of the laws. For example, Neeraj Grover (Grover, 2014) argues that, the law should move towards unification of proper law of the arbitration agreement and the underlying contract so that except for rules that cannot be derogated from, there is only one law applicable to the agreement as a whole. She argues that, it is the most balanced approach because it results in simplification, certainty and adherence to the parties' bargain where the reduced complication of applying different laws to the arbitration agreement and the underlying contract will give substantive effect to the choice of law clause stated in the contract. It will grant certainty to the process because parties will not have to familiarize themselves with nuances of separability when they will know the effect of the general choice of law clause.

While considering the above arguments, it becomes clear that, by simply applying the law governing the main contract upon the agreement to arbitrate would in itself would not result in benefits to the parties to an arbitration and instead, the validation theory seems to be the most important consideration, where the need for giving effect to the arbitration agreement, albeit with whatever law that is going to govern such agreement, holding that the agreement to arbitrate is valid remains the focal point. Therefore, one has to be vigilant of this fact in determining the choice of law or the applicable law that would govern the agreement to arbitrate.

\subsection{Application of the Proper Law of Contract at the Seat of Arbitration}

The law of the country where the arbitration is seated determines the legality of the arbitral proceedings and sets out rules and processes to assist the tribunal in its mandate. The law of the seat is known as lex arbitri as well as curial law. However, where parties to an international arbitration agreement choose for 
themselves a seat of arbitration, they usually choose a place that has no connection with either themselves or their commercial relationship. They choose a "neutral" place. By doing so, they do not necessarily intend to choose the law of that place to govern their relationship (Redfern \& Hunter, 2015).

The lex arbitri refers to both substantive and procedural law and operates as a type of platform or safety net for arbitration, even if the parties never make any use of it whatsoever. Its utility for the arbitral process lies in the fact that both the parties and the arbitrator may seek some assistance (or intervention) from the local courts in situations where neither the parties nor the arbitrator are empowered to undertake a particular action, as is the case with compelling the attendance of witnesses, enforcement of interim measures, attachment of assets and others. Equally, the mandatory rules relating to the conduct of arbitral proceedings (such as due process and party equality) or the legal requirements for the validity of awards are subject to the prescriptions laid down by the law of the seat. As a result, both the parties and the arbitrator must ensure that they have fully complied with this law otherwise the award risks being set aside. In the case of (Smith Ltd v H International, 1991) lex arbitri was defined as, “a body of rules which sets a standard external to the arbitration agreement, and the wishes of the parties, for the conduct of the arbitration. The law governing the arbitration comprises the rules governing interim measures (e.g. Court orders for the preservation or storage of goods), the rules empowering the exercise by the Court of supportive measures to assist an arbitration which has run into difficulties (e.g. filling a vacancy in the composition of the arbitral tribunal if there is no other mechanism) and the rules providing for the exercise by the Court of its supervisory jurisdiction over arbitrations (e.g. removing an arbitrator for misconduct)." Moreover, an award will most probably be refused recognition and enforcement in a third state if it has been made in violation of the lex arbitri (assuming it has not already been set aside in the seat).

It should be observed that, unlike the consensual (lex voluntatis) nature of choice of law clauses, the lex arbitri is automatic and obligatory, although domestic arbitration statutes typically distinguish between mandatory and permissive provisions in the lex arbitri. For example, the parties cannot exclude the application of Swiss procedural law to arbitral proceedings taking place in Switzerland because the local courts continue to possess jurisdiction over the proceedings and can intervene if local law so demands, or if requested by the arbitrators (Bantekas, 2015). However, the concept of subjecting an arbitration in one state to the procedural law of another has been the subject of much theoretical discussion (Redfern \& Hunter, 2015). For example, Swiss law provides that the parties to an arbitration may "subject the arbitral procedure to the procedural law of their choice". While this is possible in theory, subjecting the arbitral procedure to a procedural law of another country or to the proper law of contract would become problematic since the parties and the arbitral tribunal would need to have regard to two procedural laws, whereas the parties and the tribunal would 
have to be vigilant about the applicable mandatory laws at the seat of arbitration if they are to use a procedural law of another country. In the case of (Naviera Amazonia Peruana SA v Compania Internacional de Seguros de Peru, 1988), the court held that, there is no reason in theory which precludes parties to agree that an arbitration shall be held at a place or in country $\mathrm{X}$ but subject to the procedural laws of Y. However, the court explained that, under the principles of English law, which rest upon the territorially limited jurisdiction of our courts, an agreement to arbitrate in X subject to English procedural law would not empower our courts to exercise jurisdiction over the arbitration in X. This clearly indicates the practical difficulties that may arise in subjecting the arbitration to a different law from that of the lex arbitri.

Those who are arguing in favour of applying the choice of law selected by the parties to an arbitration proceeding held in a foreign country points out that arbitration should be delocalized. They argue that, for the sake of stretching party autonomy the law of the seat may find no compelling reason to force the parties to use local procedural rules provided that the proceedings do not violate due process rights. However, Ilias Bantekas points out that, "the idea that arbitral proceedings may somehow be 'floating' or 'delocalized' by reason of the parties' consent, namely that there will exist no particular seat and therefore no lex arbitri, is probably best reserved for the realms of imagination". Adding to this, Redfern and Hunter also observe that, in practice, however, the idea of a universal lex arbitri is as illusory as that of universal peace. Each state has its own national characteristics, its own interests to protect, and its own concepts of how arbitrations should be conducted in its territory.

With the above analysis, it is evident that, allowing the parties select the applicable law related to the arbitration process to be carried out in a foreign country is not going to help the parties that much since, at any rate, at least the mandatory rules related to arbitration must have to be followed at the seat of arbitration according to the rules of lex arbitri. Further, if a foreign law was to govern the arbitration process which is not the law of the seat of the arbitration, there would be much confusion for the parties themselves, the arbitrators and the courts of the seat, where all of whom would be utterly confused as to the nature and the extent of the applicable rules.

\subsection{Application of the Proper Law of Contract at the Country of Enforcement of the Award}

The ultimate aim of the winning party is to enforce the award in a country where the losing party has sufficient assets. The fulfillment of the arbitral process is accomplished with enforcement of the award. Without enforcement, the arbitral process has no utility. The enforcement stage is the destiny of the arbitral process (Grover, 2014). The losing party's assets may be spread across several jurisdictions and hence enforcement may be sought in more than one country. The effects of the award in the state of origin are necessarily ruled by that legal 
system, or by the different national procedural law which has ruled the arbitral proceedings, except for the mandatory provisions of the state of origin (Sammartano, 2001). Although the enforcement of foreign arbitral awards is regulated chiefly by a multilateral treaty, the 1958 New York Convention (as well as other regional conventions), this treaty allows member states to construe concepts such as public policy and arbitrability on the basis of their domestic law. However, the 1958 New York Convention does not define public policy, arbitrability or the requirements for the validity of the arbitration clause, thus leaving pertinent determinations to domestic law. Besides the general application of Article 31(1) of the Vienna Convention on the Law of Treaties 1969 (VCLT) the travaux of the 1958 New York Convention do not suggest that arbitrability and public policy must be construed from a dimension other than that prescribed under the lex fori (Fry, 2009).

In the case of (Soleimany v Soleimany, 1999), the English Court of Appeal refused to enforce an award where the transaction was not illegal under the applicable law, but was illegal under English law where the enforcement was sought. The case concerned a contract between a father and son, which involved the smuggling of carpets out of Iran in breach of Iranian revenue laws and export controls. The father and son had agreed to submit their dispute to arbitration by the Beth Din, the Court of the Chief Rabbi in London, which applied Jewish law. Under the applicable Jewish law, the illegal purpose of the contract had no effect on the rights of the parties and the Beth Din proceeded to make an award enforcing the contract. In declining to enforce the award, the English Court of Appeal stated that, the Court is in our view concerned to preserve the integrity of its process, and to see that it is not abused. The parties cannot override that concern by private agreement. They cannot by procuring an arbitration conceal that they, or rather one of them, is seeking to enforce an illegal contract. Public policy will not allow it. Further, in the case of (Eco Swiss China Ltd v Benetton Investment NV, 1999) an arbitral tribunal seated in the Netherlands found Benetton liable for wrongfully terminating an exclusive licensing agreement by which Eco Swiss was given the exclusive right to sell watches and clocks bearing the words "Benetton by Bulova" throughout Europe. Benetton challenged the award before the Dutch courts, claiming annulment on the grounds, inter alia, that the exclusive licensing agreement was anti-competitive under Art. 81 TEU and that therefore an award that enforced such an agreement was contrary to public policy. This issue had been raised neither by the parties nor by the arbitrators during the arbitration. The Dutch courts sent several questions of European law to the European Court of Justice (ECJ) for determination and the ECJ found that a violation of European community law made an award liable to be set aside by a national court, because European competition law qualified as a matter of public policy.

Form the above analysis, it becomes clear that, applying the proper law of contract at the enforcement stage would become problematic since the enforce- 
ment would be done subject to the laws and rules applicable at the country in which the enforcement is sought. Commenting on the unification of applicable laws, Neeraj (Grover, 2014) observes that, the proper law of the arbitration agreement and that of the underlying contract would be devoid of any credence if it has an evil bearing on the enforcement of the arbitral award. Therefore, parties would not be benefited if the proper law of contract was to be applied at the enforcement stage, since many of the domestic courts the world over would not like to subject themselves to a law of another country in contravention of the sovereignty of their respective state. Therefore, it becomes clear that practically it would not be possible to apply the proper law of contract at the enforcement stage.

\section{Conclusion}

International arbitration has become the most favoured form of dispute resolution in the field of international commercial agreements due to its flexibility and neutrality. Many international corporations, multinational organizations and even states have found it much more convenient to arbitrate than to litigate. When one looks at the arbitral process, one can find that there are numerous laws and rules that would govern the whole process and when it comes to international commercial arbitration in particular, it would be governed by many systems of law in different jurisdictions.

The concept of party autonomy gives the parties to an arbitration to elect the laws that would govern the agreement to arbitrate, the substantive laws governing the main contract and the procedural laws that would govern the arbitration if they wish to. However, when it comes to the selection of procedural laws, if the parties are going to select a procedural law that is not the procedural law of the seat of arbitration or the lex arbitri it was shown that many practical issues and difficulties may have to be faced by all the parties involved in the arbitral process. Furthermore, when it comes to the applicable law at the enforcement stage, parties are not at liberty to decide on the applicable laws and hence, it would be governed by the laws of the country where the enforcement of the award is sought.

In trying to apply the proper law of contract at each and every stage of the arbitral process, one may argue that it would help to keep things simple, take away any uncertainties and would help to strengthen the concept of party autonomy. However, from the above analysis, it seems clear that, such an endeavour would be practically difficult since an international commercial arbitration would invite the laws and rules of several legal systems and jurisdictions which may not be compatible with one another in every aspect. Therefore, if one is trying to harmonize the applicable law to an arbitral process, that would have to be done through an international legal instrument which would have to incorporate all the substantive and procedural aspects involved in an arbitral process to a single and coherent legal framework to govern all the aspects of an arbitral process 
which if not difficult is impossible. Further, substantive evidence has not been shown for the need for applying the proper law of contract throughout the arbitral process in order to give the parties who are involved with an arbitration in settling their disputes. Therefore, it can be shown that adopting the proper law of contract throughout the arbitral process is neither practical nor warranted in literature and therefore, it is a utopian thought with less pragmatic significance at least in the contemporary world.

\section{Conflicts of Interest}

The author declares no conflicts of interest regarding the publication of this paper.

\section{References}

Abuja International Hotels Ltd. v. Meridien SAS, EWHC 87 (HC 2012).

Bantekas, I. (2015). An Introduction to International Arbitration. Cambridge: Cambridge University Press. https://doi.org/10.1017/CBO9781316275696

Born, G. (2009). International Commercial Arbitration. Hague: Kluwer.

C v D, EWCA Civ 1282 (CA 2007).

Eco Swiss China Ltd v Benetton Investment NV, ECR I-3055 (1999).

Fry, J. D. (2009). Désordre Public International under the New York Convention: Whither Truly International Public Policy. Chinese Journal of International Law, 8, 81-134. https://doi.org/10.1093/chinesejil/jmn043

Fung Sang Trading Ltd. v. Kaisun Sea Products \& Food Co. Ltd., YBCA 289 (SC Hong Kong 1992).

Gosset v. Carapelli, Cass. CIV. Lere (May 7, 1963).

Grover, N. (2014). Dilemma of the Proper Law of the Arbitration Agreement: An Approach towards Unification of Applicable Laws. Singapore Law Review, 32, 227-256.

Heyman v Darwins Ltd., AC 356 (CA 1942).

ICC (1977). The International Solution to International Business Disputes: ICC. Paris, France.

Mme X v Banque Privée Edmond de Rothschild, ILPr (2013).

Moses, L. (2012). The Principles and Practice of International Commercial Arbitration. Cambridge: Cambridge University Press. https://doi.org/10.1017/CBO9780511920073

Motunui Ltd. v. Methanex Spellman, 1 NZLR 95 (HC 2004).

National Thermal Power Corporation v Singer Company, (3) SCC 551 (SC 1992).

Naviera Amazonia Peruana SA v Compania Internacional de Seguros de Peru, 1 Lloyd's Rep 116 (CHC 1988).

Pearson, S. (2013). Sulamerica v. Enesa: The Hidden Provalidation Approach Adopted by the English Courts with Respect to the Proper Law of the Arbitration Agreement. Arbitration International, 29, 115-126. https://doi.org/10.1093/arbint/29.1.115

Redfern, A., \& Hunter, M. (2015). International Arbitration. Oxford: OUP.

Sammartano, M. (2001). International Arbitration: Theory and Practice. Paris: Kluwer.

Savage, E. G. (1999). International Commercial Arbitration. Alphen aan den Rijn: Kluwer. 
Scott v Avery, 5 CAS 811 (HL 1856).

Smith Ltd v H International, 2 Lloyd's Rep 127 (CHC 1991).

Soleimany v Soleimany, QB 785 (SC 1999).

Sulamerica CIA Nacional de Seguros S.A. and others v. Enesa Engenharia S.A. and others, EWHC 42 (HC 2012).

XL Insurance Ltd. v. Owens Corning, 2 Lloyd's (CHC 2000). 